\title{
Detecção de anticorpos anti-Leishmania infantum syn chagasi em cães de São José do Rio Preto, São Paulo
}

\author{
Anti-Leishmania infantum syn chagasi antibodies in dogs from São José do Rio Preto, \\ São Paulo
}
Carla Daniela Dan DE NARDO ${ }^{1}$; Cláudio Nazarethian ROSSI ${ }^{2}$; Marcia Dalastra LAURENTI ${ }^{3}$; Mary MARCONDES $^{1}$

\author{
${ }^{1}$ Universidade Estadual Paulista Júlio de Mesquita Filho, Araçatuba - SP, Brasil \\ ${ }^{2}$ Departamento de Clínica Médica da Faculdade de Medicina Veterinária e Zootecnia da \\ Universidade de São Paulo, São Paulo - SP, Brasil \\ ${ }^{3}$ Departamento de Patologia da Faculdade de Medicina da Universidade de São Paulo, São Paulo - SP, Brasil
}

\begin{abstract}
Resumo
A leishmaniose visceral (LV) é uma zoonose que vem se expandido por todo o território paulista desde 1998, quando foi identificado o primeiro caso canino autóctone, no município de Araçatuba. O objetivo do presente estudo foi determinar a ocorrência de anticorpos anti-Leishmania infantum syn chagasi em amostras de soro de 584 cães de São José do Rio Preto, São Paulo, área não endêmica para a doença. Cinco cães $(0,86 \%)$ foram soro reagentes pela técnica de ELISA e um (0,17\%) por imunocromatografia. A reação de imunofluorescência indireta, realizada em 138 animais que possuíam densidades ópticas acima ou próximas ao ponto de corte do ELISA evidenciou dois cães $(1,45 \%)$ com títulos acima de 1:40. Apenas um animal foi sororeagente nas três técnicas sorológicas. Apesar deste cão não apresentar histórico de deslocamento para áreas endêmicas, havia sido adquirido em região com casos caninos e humanos de LV. Os resultados obtidos no presente estudo fazem supor que não existiam casos autóctones de LV canina na população estudada.
\end{abstract}

Palavras-chave: Leishmaniose visceral. Canina. ELISA. Imunocromatografia. Reação de imunofluorescência indireta.

\begin{abstract}
Visceral leishmaniasis (VL) has been a widespread zoonosis in São Paulo since 1998, when the first autochthonous canine case was identified in Araçatuba. The aim of this study was to determine the occurrence of anti-Leishmania infantum syn chagasi antibodies in serum samples of 584 dogs from São José do Rio Preto, São Paulo, a non endemic area for the disease. Five dogs $(0.86 \%)$ seroconverted by ELISA and one $(0.17 \%)$ by immunochromatography. The indirect immunofluorescent reaction, carried out in 138 animals whose optical densities were above or close to ELISA's cutt-off point, evidenced two dogs (1.45\%) with titers above 1:40. Only one dog was serum-reactive on the three techniques. Although there was not a history of displacing this animal to endemic areas, the dog had been acquired in a region with canine and human cases of VL. These results suggests that there were no autochthonous cases of canine VL in this population.
\end{abstract}

Keywords: Visceral leishmaniasis. Canine. ELISA. Immunochromatography. Indirect immunofluorescent reaction.

A leishmaniose visceral (LV) é uma zoonose cujo agente etiológico no Brasil é a Leishmania infantum syn chagasi, transmitida através da picada de dípteros do gênero Lutzomyia infectados ${ }^{1,2}$. O primeiro caso canino autóctone no Estado de São Paulo foi identificado no município de Araçatuba, em 1998. Desde então vem se disseminando e, apesar dos esforços para conter sua expansão, verifica-se que vai se dispersando pelo território paulista ${ }^{3}$.
Em São José do Rio Preto, município situado na região noroeste do Estado, não foram confirmados, até o momento, casos caninos ou humanos autócto-

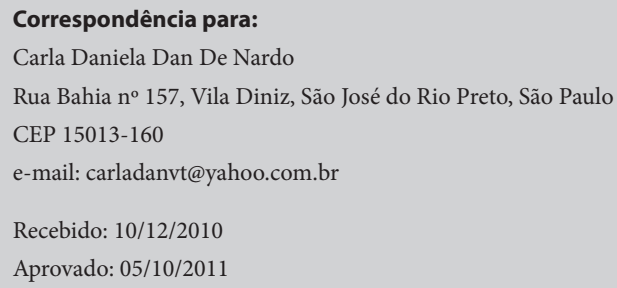


nes, nem a presença do vetor. Segundo a classificação epidemiológica, São José do Rio Preto, no tocante à LV, é considerado munícípio silencioso, não receptivo e vulnerável, ou seja, município em que não há confirmação de casos autóctones humanos e caninos, não há a presença do vetor, mas existe a possibilidade de circulação de fontes de infecção ${ }^{4}$. As técnicas sorológicas recomendadas atualmente pelo Ministério da Saúde do Brasil para o inquérito epidemiológico canino são a reação de imunofluorescência indireta (RIFI) e o ELISA, sendo que este último é considerado como teste de escolha para inquéritos populacionais. O Ministério da Saúde recomenda o teste de ELISA indireto para a triagem inicial dos cães suspeitos e a RIFI para a confirmação dos casos positivos ${ }^{1}$.

Partindo-se da hipótese de que pode estar ocorrendo transmissão nesse município, presente estudo teve por objetivo pesquisar a presença de anticorpos anti-Leishmania infantum em amostras de cães provenientes do município e região administrativa de São José do Rio Preto.

Foram avaliados soros de 584 cães, encaminhados para consultas no Hospital Veterinário (HV) do Centro Universitário de Rio Preto, de janeiro a dezembro de 2008. Amostras de soro dos 584 animais foram submetidas ao teste de ELISA indireto e imunocromatografia. Para a realização da técnica de imunocromatografia utilizou-se um Kit comercial (Kalazar Detect Animal Rapid Test - Inbios International, Inc. Seattle, WA) que detecta a presença de anticorpos anti-Leishmania sp no soro de animais, utilizando o antígeno recombinante $\mathrm{rK} 39^{5}$. Os resultados deste teste foram determinados individualmente, de forma qualitativa (positivo ou negativo), conforme recomendação do fabricante. Os cães que apresentaram densidades ópticas próximas e acima do ponto de corte do ELISA ou resultado positivo por imunocromatografia (138 cães) foram novamente testados por meio da reação de imunofluorescência indireta (RIFI). Apenas sete cães (dois soro reagentes por ELISA e cinco com den- sidades próximas ao ponto de corte, mas todos negativos nas demais técnicas sorológicas) retornaram ao $\mathrm{HV}$, quando foram colhidas amostras de sangue total de todos e realizadas punções biópsias aspirativas de linfonodos de cinco deles para a realização da técnica da PCR para pesquisa de Leishmania $\mathrm{sp}^{6}$.

A reação de ELISA foi realizada de acordo com Lemos et al. ${ }^{5}$ com algumas modificações. Brevemente, placas foram sensibilizadas com lisado de formas promastigotas de L. (L.) chagasi, cepa MHOM/BR/72/ cepa46, na concentração de $10 \mu \mathrm{g} / \mathrm{mL}$ em tampão carbonato $0,05 \mathrm{M} \mathrm{pH} \mathrm{9,6} \mathrm{por} 18$ horas a $4{ }^{\circ} \mathrm{C}$. Os soros foram testados na diluição de 1:400, utilizando o conjugado anti-IgG total de cão ligado à peroxidase (A40-123P Bethyl, Montgomery, USA) na diluição de 1:80000 em PBS-T. A revelação da reação foi feita com solução de tetrametilbenzidina dihidroclorada (TMB) (Código 55214BD Biosciences Pharmingen, San Diego, USA) e as densidades ópticas (D.O.) foram determinada em leitor de ELISA (Labsystems Multiskan EX - Thermo Fisher Scientific Inc. Waltham, MA) utilizando-se filtro de $450 \mathrm{~nm}$. Os resultados foram expressos pela média da densidade óptica obtida dos soros em duplicata. Como controle positivo da reação utilizou-se soro de dois cães parasitologicamente positivo com elevados títulos de IgG anti- $L$. chagasi proveniente do município de Araçatuba, São Paulo; e como controle negativo, soro de cinco cães proveniente de área não endêmica para a doença. A determinação do ponto de corte $(0,274)$ foi realizada com 30 amostras de soros de cães provenientes de área não endêmica.

A técnica de RIFI foi realizada de acordo com Silva et al. ${ }^{7}$. Resumidamente, lâminas previamente sensibilizadas com formas promastigotas de $L$. (L.) chagasi foram incubadas com os soros testes na diluição de 1:40 por 30 minutos à $37^{\circ} \mathrm{C}$. Anticorpo anti-IgG de cão fluoresceinado (FITC conjugate - Sigma, USA) na diluição de 1:100 em azul de Evans, foi empregado como conjugado. Após leitura em microscopia de fluorescência, as 
amostras positivas na diluição de 1:40 foram tituladas a partir de 1:80 até 1:1280. Os soros controles, positivos e negativos, empregados no ELISA foram também utilizados como controle para a RIFI.

Por meio da técnica de ELISA foram identificados cinco cães soro reagentes, dos quais um foi também soro reagente nas outras duas provas sorológicas, determinando uma ocorrência de soropositivade por ELISA de $0,86 \%$. Um cão $(0,17 \%)$ foi positivo por imunocromatografia, e a RIFI evidenciou dois animais $(1,45 \%)$ com títulos acima de 1:40. Em função das recomendações do Ministério da Saúde do Brasil, foi considerado infectado apenas o cão soro reagente por ELISA e RIFI, e que também foi positivo por imunocromatografia, evidenciando uma ocorrência de soropositivade de $0,17 \%$ na população estudada. Tais resultados se aproximam daqueles obtidos em um inquérito epidemiológico realizado no município entre novembro de 1998 e junho de 2000, que identificou uma ocorrência de $0,6 \%$, com confirmação de apenas um animal parasitologicamente positivo que, no entanto, era proveniente de área endêmica para $\mathrm{LV}^{8}$. A opção pelos testes sorológicos utilizados no presente estudo se baseou nas recomendações do Ministério da Saúde e na avaliação de um teste rápido de imunocromatografia que utiliza um antígeno recombinante

\section{Referências}

1. BRASIL. Ministério da Saúde. Secretaria de Vigilância em Saúde. Departamento de Vigilância Epidemiológica. Manual de vigilância e controle da leishmaniose visceral. Brasília: Ministério da Saúde, 2006. 120 p.

2. MAURICIO, I. L.; STOTHARD, J. R.; MILES, M. A. The Strange case of Leishmania chagasi. Parasitology Today, v. 16, n. 5, p. 188-189, 2000.

3. CAMARGO-NEVES, V. L. F.; KATZ, G. Ações controle da leishmaniose visceral americana implementadas na região oeste do Estado de São Paulo. Revista Sociedade Brasileira de Medicina Tropical, v. 32, p. 63-64, 1999.

4. SÃO PAULO. Secretaria de Estado da Saúde. Classificação epidemiológica dos municípios para a leishmaniose visceral americana. Boletim Epidemiológico Paulista, v. 5, n. 52, p. 20-25, 2008 .

5. LEMOS, E. M.; LAURENTI, M. D.; MOREIRA, M. A. B.; REIS, A. B.; GIUNCHETTI, R. C.; RAYCHAUDHURI, S.; DIETZE, R. Performance of a rapid diagnostic test (Kalazar Detect) in
(rK39) o que, supostamente, poderia conferir maior especificidade ao teste ${ }^{5}$.

A técnica de PCR foi realizada em sete dos 584 animais na tentativa de confirmar a presença do parasito. Desses cães, somente dois eram soro reagentes (ELISA), no entanto, em nenhuma das sete amostras foi identificado o DNA do parasito.

Apesar do único cão soro reagente nas três técnicas sorológicas não apresentar histórico de deslocamento para municípios endêmicos, este animal havia sido adquirido há um ano em região com casos caninos e humanos de LV com um mês de idade. Desta forma, há que se considerar a possibilidade de infecção prévia, antes de seu deslocamento para São José do Rio Preto. Por se tratar de doença, na maioria das vezes, de evolução crônica, é possível que o cão tenha sido infectado no local de nascimento, antes de ser transferido par ao município em estudo ${ }^{9,10}$.

As percentagens de soro reatividade encontradas no presente estudo, aliadas ao fato do único animal que apresentava sorologia positiva por mais de uma técnica ter sido adquirido em área endêmica para LV, faz supor que não existiam casos autóctones de LVC na população estudada, e que São José do Rio Preto deve ser, ainda, área não endêmica para leishmaniose visceral canina.

dogs with and without signs of the disease. Acta Tropica, v. 107 , n. 2, p. 205-207, 2008.

6. NUNES, C. M.; DIAS, A. K. K.; GOTTARDI, F. P.; PAULA, H. B. de; AZEVEDO, M. A. A. de; LIMA, V. M. F. de; GARCIA, J. F. Avaliação da reação em cadeia pela polimerase para diagnóstico da leismaniose visceral em sangue de cães. Revista Brasileira de Parasitologia Veterinária, v. 16, n. 1, p. 5-9, 2007.

7.SILVA, R. M.; LAURENTI, M. D.; GOMES, A. C.; NOGUEIRA, Y. L. TG-ROC analysis of immunofluorescence assays in canine visceral leishmaniasis diagnosis. Revista de Saúde Pública, v. 43, n. 6, p. 1044-1053, 2009.

8. SAVANI, E. S. M. M.; VON SCHIMONSKY, B.; CAMARGO, M. C. G. O.; D’AURIA, S. R. N. Vigilância de leishmaniose visceral americana em cães de área não endêmica. Revista Saúde Pública, v. 37, n. 2, p. 260-262, 2003.

9. PANGRAZIO, K. K.; COSTA, E. A.; AMARILLA, S. P.; CINO, A. G.; SILVA, T. M. A.; PAIXÃO, T. A.; COSTA, L. 
F.; DENGUES, E. G.; DIAZ, A. A. R. Tissue distribution of Leishmania chagasi and lesions in transplacentally infected fetuses from symptomatic and asymptomatic naturally infected bitches. Veterinary Parasitology, v. 165, n. 3-4, p. 327-331, 2009.
10.SILVA, S. M.; RIBEIRO, V. M.; RIBEIRO, R. R.; TAFURI, W. L.; MELO, M. N. First report of vertical transmission of Leishmania (leishmania) infantum in a naturally infected bitch from Brazil. Veterinary Parasitology, v. 166, n. 1-2, p. 159$162,2009$. 